\title{
ANALYSIS OF ECONOMIC GROWTH AND INCOME INEQUALITY IN ROMANIA IN THE PERIOD 1990-2019
}

\author{
Bianca VEZENTAN \\ Doctoral School of Economic Sciences - University of Oradea, Oradea, Romania \\ vezentanbianca@yahoo.com
}

\begin{abstract}
The paper aims to analyze the relationship between economic growth and income inequality in Romania in the period 1990-2019. The "Gross Domestic Product" (GDP) per capita indicator from the World Bank database was used to show the evolution of economic growth, and the GINI Coefficient was extracted from the Standardized World Income Inequality database to analyze income inequality. Romania's macroeconomic result (GDP per capita) registered a continuous growth trend in the period 1990-2019. The Gini coefficient has followed the same dynamics. At first sight, this fact highlights that the phenomenon of economic growth has widened the gap between the rich and the poor in Romania in the examined period.
\end{abstract}

Keywords: economic growth, income inequality, GDP per capita, Gini coefficient

Jel Codes: O47, O15, E01

\section{Introduction}

The relationship between economic growth and the evolution of income inequality is intensively studied by the economic literature in recent years, following the conclusions of various studies showing that the phenomenon of economic growth and development is accompanied by income distribution effects that are not always fair. More specifically, even if economic well-being in general increases, by increasing the wealth obtained, this may have the effect of increasing inequality in the distribution of income in society. The topic is of interest to policy makers as well, with the emergence of concepts such as social cohesion and inclusive development. Both are objectives of specific European Union (EU) policies. Thus, the promotion of social cohesion is the goal of the policy of the same name in the $\mathrm{EU}$, and social inclusion is also pursued through community social policy.

As an EU Member State, Romania aligns with these policies and implements measures at national level, through its own social policies.

This paper aims to analyze the relationship between economic growth and income distribution in Romania in the period 1990-2019, based on the time series extracted from the World Bank database and the Standardized World Income Inequality Database.

The paper is structured as follows: after the introduction, in the second section, the concepts we work with are presented, then a short literature review on the relationship between economic growth and income inequality is inserted; in the fourth section the evolutions of the two statistical indicators are described and analyzed; the fifth section comprises a discussion of the findings and the last part is dedicated to the conclusions.

2. Conceptual basis 


\subsection{Economic growth}

Most economists agree that the phenomenon of economic growth means an increase in the amount of useful economic effects obtained in a given period of time (lonescu, 2005, p.162).

In the economic literature this concept is used broadly and narrowly. In a broad sense, it means the increase of national wealth, national income, domestic product, in a given period of time. In a narrow sense, it refers to the positive evolution of the national income or the domestic product per capita in a given period. Regardless of the meaning, economic growth targets the quantitative side of economic results, as a whole and per capita, and involves not only the expansion of production potential, but also their combination with a higher economic yield.

The measurement of economic growth is done using statistical indicators such as gross domestic product, gross national product or national income.

In practice, the appreciation of the standard of living of a nation is achieved through the gross domestic product per capita, the purpose of economic policies being to stimulate its growth.

In order to analyze the evolution of the gross domestic product per capita in the case of Romania, we extracted time series from the World Bank database, opting for the Purchasing Power Parity (PPP) unit of measurement, for the period 19902019.

\subsection{Income inequality}

The Gini coefficient is the most common tool for measuring income inequality internationally. It measures the distribution of income, comparing the income statement of each household with the income statement of all other households. By construction, the coefficient is expressed as a percentage value between 0 and 100. A Gini coefficient equal to 0 indicates perfect income equality; a Gini coefficient equal to 100 would mean that all the income obtained in the economy belongs to a single household, which would indicate the perfect income inequality. We used the Gini coefficient available for Romania from the Standardized World Income Inequality Database. In this database, the calculation of this coefficient is based on observations collected from the OECD Income Distribution Database, Socio-Economic Database for Latin America, EUROSTAT, World Bank and national statistical offices (Solt, 2020).

\section{The relationship between economic growth and income inequality: a brief literature review}

The issue of income inequality has preoccupied economists and gained new importance since the Great Recession. Some authors have argued that income inequality is a major problem of our time, supported by the empirical observation that market income inequality - measured by the Gini coefficient - has increased substantially since the mid-1970s in industrial economies; a development that contrasts unfavourably with a long previous period, when inequality fell from the predominantly high levels of the early twentieth century (Peterson, 2017). "A high 
and persistent income inequality is considered intrinsically undesirable. However, assessing whether higher-income inequality is delaying economic growth has proven to be a challenge and is much disputed in the literature. Theoretically, the effect can go both ways. An increase in income inequality resulting, for example, from substantial rewards to risky entrepreneurship and innovation, could stimulate economic growth. In contrast, greater inequality could affect economic growth if low-income households are persistently less productive due to slower accumulation of human capital and higher financial exclusion" (Aiyar and Ebeke, 2020). According to some empirical studies, there is little consensus. Some studies have found a significant and negative effect of inequality on growth and its duration (Ostry and Berg, 2011; Ostry, et.al, 2014; Cingano, 2014), and others have found no systematic negative effect of inequality on growth (i.e., Forbes, 2000; Kraay, 2015). Barro (2000) reports that the growth-inequality relationship is sensitive, respectively, to the level of incomes in the country and to the time horizon taken into account, while other authors have sought to demonstrate that the relationship is nonlinear or oscillating (Banerjee and Duflo, 2003; Brueckner et al., 2015).

A number of studies examine the variability of US state data to show that inequality of opportunity negatively affects the future income growth of the poor and positively affects that of the rich (Marrero and Rodríguez, 2013; Hsieh et al., 2013). The idea is that inequality of opportunity can affect economic growth, as it prevents the accumulation of human capital by low-income people. Moreover, perceptions of inequality of opportunity, which affect individual aspirations, can also reduce investment in human capital.

In the international literature, the study on inequality of opportunity has received less attention, especially due to the difficulty of measuring equal opportunities in a comparable way between countries. However, there has been significant recent progress in this area, with measured equality of opportunity, using cross-border data on different indices of intergenerational mobility, such as the elasticity of a person's income (or education) to parental income (or education) (Aiyar and Ebeke, 2020).

In economies of low opportunity, income inequality has a greater influence on growth. An increase in income inequality tends to take root over generations due to various market failures related to social stratification. This delays growth, for example by impeding the development of human capital or causing the misallocation of talent. And on the other hand, in countries with high equal opportunities, an increase in income inequality is slightly reversed precisely because people on low incomes have access to the same opportunities as others. Therefore, in such societies, an increase in income inequality is less detrimental to growth (Aiyar and Ebeke, 2020).

Inequality of opportunity could influence the marginal effect of income inequality on growth, taking into account various mechanisms. Thus, Aiyar and Ebeke (2020) provide three examples. First of all, the existence of unequal access to education could lead to the loss of educational opportunities, following a shock of income, therefore to a slower increase in future productivity. More precisely, this idea has been researched in the literature, where income inequality in the presence of financial constraints prevents poor families from investing optimally in schooling, thus affecting growth (Galor and Zeira, 1993). Second, in an economy characterized by structural rigidities in labour markets, a shock that worsens the 
distribution of income could further disadvantage outsiders; otherwise it could create unequal opportunities for insiders and outsiders."The effects of hysteresis could translate this disadvantage into longer-term growth"(Aiyar and Ebeke, 2020). The third mechanism could be linked to unequal access to finance. An income shock in the presence of credit constraints could be understood as investment opportunities wasted among the lower percentages of income distribution, resulting in lower aggregate growth. Benabou (1996) and Getachew (2010) show that when the amount that can be borrowed is rationed, an idiosyncratic credit shock can perpetuate inequality and reduce growth. "Due to declining yields, resource-poor households tend to have the highest marginal return on capital and when these high-yield investment opportunities are abandoned, the aggregate productivity suffers" (Aiyar and Ebeke, 2020).

Breunig and Majeed (2020) conducted recent research and focused on the impact of income inequality on economic growth. They extended their work by asking whether inequality and poverty, separately or jointly, have an impact on economic growth. Inequality has been assumed to negatively affect growth through several channels. Researchers have argued that inequality can lead to underinvestment in education, health and physical capital, leading to lower growth. Such underinvestment may be linked to a lack of resources, namely poverty, rather than inequality itself. She argues that the view of poverty is an additional channel that can hinder economic growth. Poverty and inequality can also interact to have a negative impact on growth. Likewise (Stiglitz, 2013) and others have argued that inequality can compromise institutions that spread the welfare of all members of society. The relationship between income inequality and economic growth has been extensively studied over the past 25 years, with research reporting a number of findings, including claims that inequality is detrimental to growth, that inequality is irrelevant to growth, and that inequality helps growth. The theory is ambiguous in terms of expected effects. Inequality can affect economic growth in a number of complex ways and through different channels (Breunig and Majeed, 2020). The literature has shown that poverty can have a negative impact on investment and GDP growth, especially when financial markets are not well developed. López (2006) support the hypothesis that poverty delays growth through various channels, including education, institutions, health, and physical capital accumulation.

Breunig and Majeed (2020) find that inequality interacts with high levels of poverty to have a negative and significant impact on economic growth. In other words, for higher levels of poverty, inequality negatively affects economic growth. This negative impact increases as poverty increases.

Another conclusion of these does not suggest that inequality has a positive role to play in economic growth. There are a variety of reasons why countries may want to reduce inequality, even if there is no impact on economic growth. These reasons may include the impact of inequality on social cohesion and institutions.

On the other hand, Islam and McGillivray (2020) consider that wealth inequality is certainly important in the relationship between economic growth and income inequality, in recent years increasing interest in the study of wealth inequality. Oxfam (2016) notes that the richest 62 people in the world have the same wealth as the poorest half of the world combined.

The ratio of billionaire wealth to GDP is also used as an alternative measure of wealth inequality. Empirical results suggest that wealth inequality has significant 
negative effects on cross-border economic growth. This statistically significant negative impact of wealth inequality on growth persists even when measures of income and wealth inequality are included in the same specification, which clearly demonstrates the dominance of wealth inequality over income inequality in relation to inequality and growth.

Other authors (i.e., Howarth and Kennedy, 2016) consider that in advanced industrial societies, the level of rising inequality has strongly contributed to the gap between per capita income and the Sustainable Economic Welfare Index (ISEW), which is now called Genuine Progress Indicator (GPI). Although income growth is often interpreted as a measure of increasing social welfare, environmental economists have long argued that the growth process generates a wide range of social and environmental costs that serve to decouple the relationship between wealth and material prosperity (Victor, 2008).

The relationship between income inequality and economic growth has been extensively studied in recent years, with a number of findings, including claims that inequality is detrimental to growth, that inequality is irrelevant to growth, and that inequality helps growth. The theory is ambiguous in terms of expected effects. Inequality can affect economic growth in a number of complex ways and through different channels.

\section{The evolution of the gross domestic product and of the income distribution in Romania in the period 1990-2019}

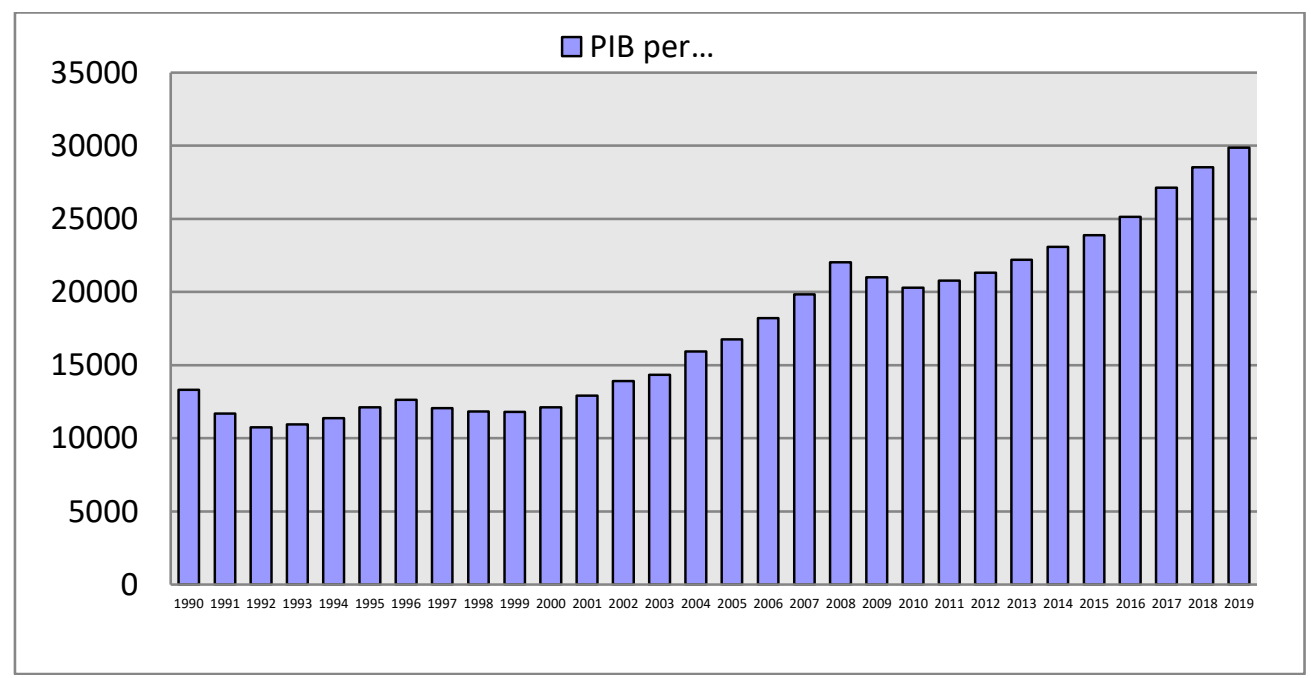

Figure 1: Evolution of the GDP per capita indicator for the period 1990-2019 (PPP, 2007 USD international constant)

Source: World Bank data processing, 2021

The gross domestic product per capita registered an increasing trend in the analyzed period, from 13,302.47 USD in 1990 to 29,857.64 USD in 2019, representing an increase of 2.16 times in 30 years. Starting with the analysis of the evolution of GDP in 1990, it gradually decreases until 1992 to $10,757.39$ USD. 
It is easy to see that 1990 is the first year of the new power after the fall of the communist regime. The revolution that took place in Romania in 1989 produced a multitude of changes in society. With the fall of this regime, the new power wanted to replace the socialist economy with the market one, based on free competition, Romania being in a period of transition to this economy. Thus, in the following years there was a period of search and redefinition with ascents and descents. After the revolution, the state gradually but not completely withdrew from its role of ensuring welfare (Ferge, 1997) because before the revolution the state was the main means of achieving social rights for all citizens.

The aim was to include the whole population in one form or another of protection, people were obliged by law to find a job, work being compulsory, but at the same time, the job was practically guaranteed by state and the right to an income was established as a right based on citizenship. There follows a slight period of economic recovery, Romania managing to recover between 1993 and 1996 registering a value from $10,936.72$ USD, to $12,627.20$ USD, again following a worsening of the economic situation until 1999 when the value of GDP- reaches $11,803.37$ USD. An explanation for this situation may be due to the fact that after the Revolution the possibility of early retirement was introduced as an alternative to unemployment. Thus, in 1997 the number of pensioners increased by exceeding 400,000 the number of employees, this circumstance is due both to the low number of employees and their desire to move in a new direction, ie to the private one. Thus, the decrease in the number of the active population was made both at the expense of the number of unemployed and at the expense of the decrease in the number of the employed population. From 2000 to 2008, the value of GDP increased rapidly from USD 21.09 .55 to USD 22,044.30 and decreased again in 2009-2010 due to the economic and financial crisis. Georgescu (2013) states that the net flows of FDI (Foreign Direct Investment) in Romania amounted to values between 5 and 9 billion euros per year, in 2007 remaining in this range (7.25 billion euros) and reaching a peak in 2008 (9.5 billion euros), in 2009 they collapsed to 3.5 billion euros.

Despite a slight recovery in international capital flows recorded globally in 2010 , in Romania net FDI flows continued their contraction, falling to 2.2 billion euros, and in 2011 and 2012 falling even below 2 billion euros, respectively at only $1 / 5$ of the level recorded in the pre-crisis period. And from 2011 GDP grows rapidly until 2019 to $29,857.64$ USD, a year that records the highest value of GDP in the analyzed period. In fact, both the final aggregate consumption by sustainability according to data taken from Eurostat increased steadily from 2010 to 2019, and exports and imports by EU Member States had the same upward trend according to statistics taken from the elected site.

Based on data extracted from the Standardized World Income Inequality Database, the Gini Coefficient registers an ascending trend for the analyzed period, from the value of 22 in 1990 to 33.8 in 2019. It increases considerably from the beginning of the analyzed period until 2007 inclusively. At the same time, EUROSTAT statistics on the at-risk-of-poverty rate according to the poverty line have the same upward trend. The Gini coefficient starts to decrease from 2007 from 33 to 2010 to 32.6 . 


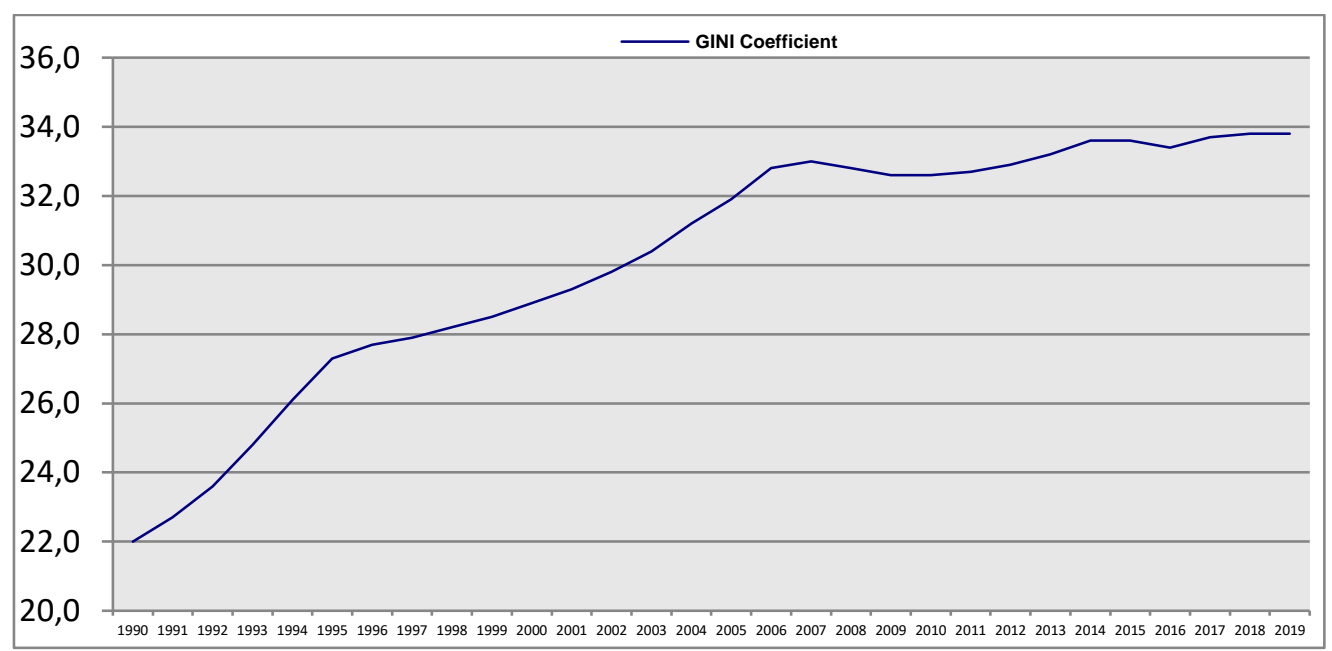

Figure 2: The evolution of the Gini coefficient in Romania during 1990-2019

Source: processing according to Standardized World Income Inequality Database, 2021

Moreover, the poverty risk rate according to the poverty line decreases from 2007 from 24.6 percent to 21.6 percent in 2010, increasing to increase by 2015 to 24.4 percent. Situation that also happens in the case of the Gini coefficient which increases until 2015 reaching the value of 33.6 and the year 2016 indicates a slight decrease to 33.4 and will increase again until 2019 when it registers the value of 33.8. This situation is influenced by the gradual decrease of the participation rate in education and training from 1.6 percent in 2011 to 0.9 percent in 2018.

According to Molnar (2010), "inequality is considered too great and unjust due to the huge gap between the living conditions of the majority of the population and the luxurious life of the rich, the well-known fact that many of the great and very high fortunes and incomes come from activities or capital accumulated in the underground economy, by breaking the law or by exploiting the weakness of the legal system, as well as by acts of corruption, while many poor people have neither the opportunity nor the possibility / ability to get a job, with much less one that allows for a decent income".

The value of the statistical correlation coefficient between the two time series is 0.89 . Its value indicates a positive association between the two variables, an association that is statistically significant, a conclusion obtained after applying the ANOVA test, which indicates a $P$ value of $1.64 \mathrm{E}-23$.

The coefficient of determination is 0.7921 , a value also high, indicating the close link between them, namely that the variation of one variable can be determined in proportion of $79 \%$ of the variation of the other, provided that the other factors remain constant. It is therefore suggested that the two variables evolve closely related to each other, respectively the growth of GDP per capita is related to the increase of income inequality.

As we can see in Figure 3, the two considered variables (logGDP per capita and Gini coefficient) are tightly evolving in the examined period of time, the series values are placed on both sides of the regression line. 


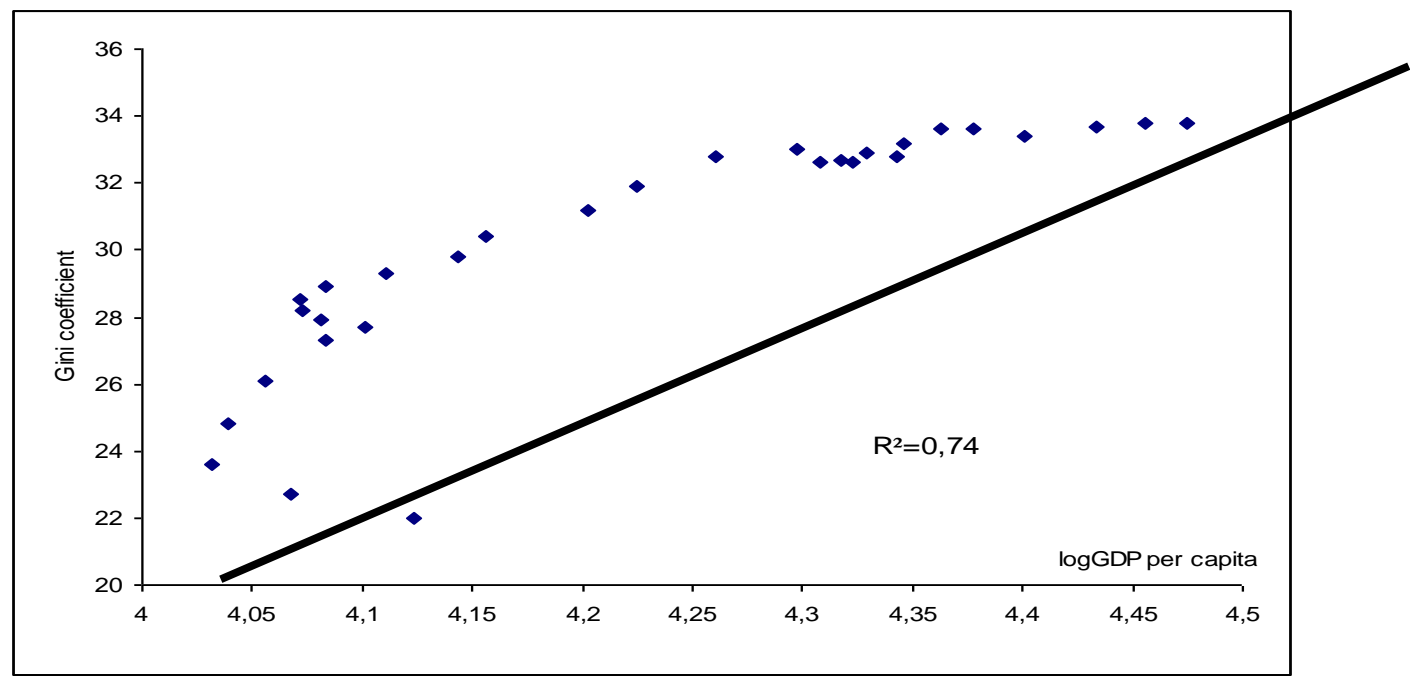

Figure 3: Dependence between logGDP per capita and Gini coefficient, in Romania (1990-2019)

Source: author's own computation based on World Bank and Standardized World Income Inequality Data, 2021

I used another statistical indicator to highlight the phenomenon of economic growth in Romania, namely, GDP per capita growth (aggregates on constant 2010 US dollars) from World Bank database.

The figure 4 highlights the evolution of this indicator for the period of 1991 to 2019. We can notice the first years, until 1993, a period of negative growth followed a positive evolution and then a fall in 1997 to 1999.

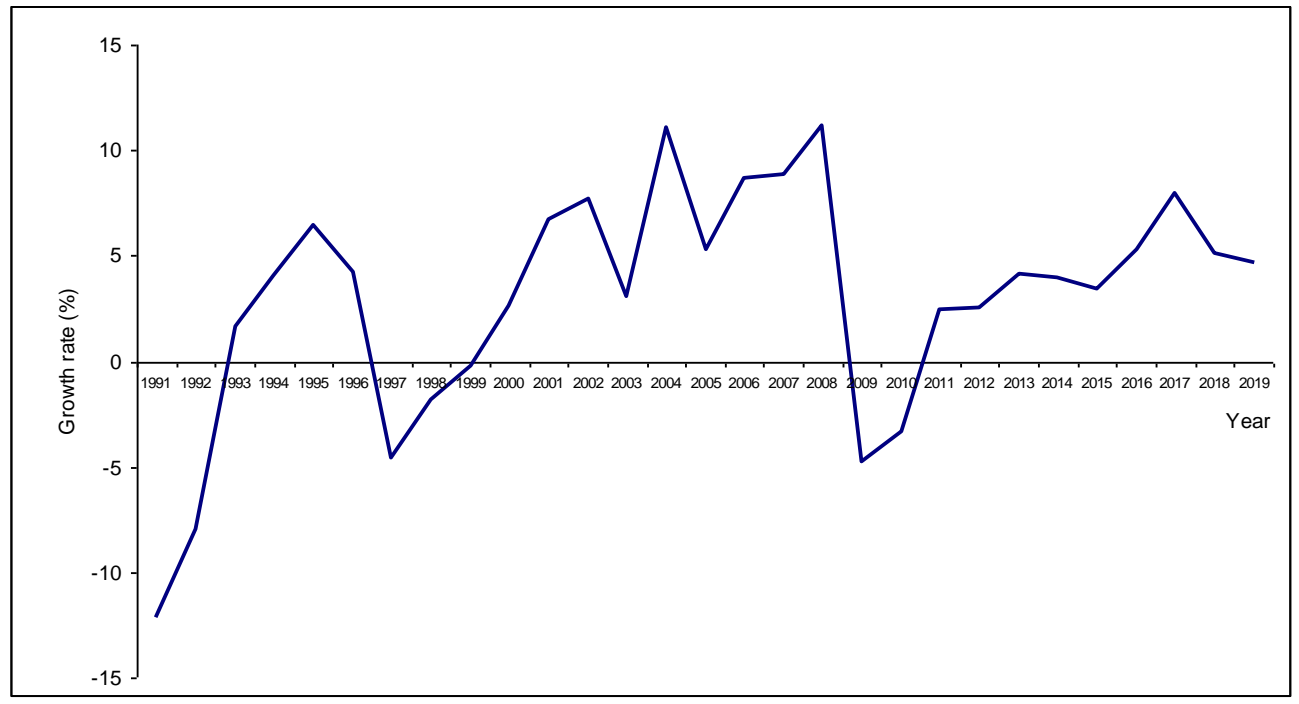

Figure 4: Dynamics of growth rate in Romania (1991-2019)

Source: author's own computation based on World Bank data, 2021 
The period of 1999 -2008 the Romanian economy registered positive values of the growth rate. The effects of international crisis are obvious in 2009-2010, with a fall of the growth rate to negative values. After 2010, the trend is ascendant, excepting the last years (2018-2019). In spite of this sinusoidal evolution, the upward trend of the growth rate is obvious. Meanwhile, the income inequality registered a similar trend.

\section{Discussion}

As we said in the GDP analysis, the transition period from the socialist economy to the market economy influences the relationship between GDP and the Gini coefficient. At the beginning of the period, inequality increased because many households suffered higher or lower income losses due to high inflation and the economic recession, and others became richer, by right or wrong means. Later, inequality increased due to the increase in property incomes, salaries and incomes from self-employed activities related to certain professions and jobs, given the persistence of a large number of low and very low income households, related to lack of qualifications and employment opportunities, as well as large family responsibilities (Molnar, 2010).

Another aspect of the considerable disagreement regarding the effect of inequality on economic growth is addressed by (Shin, 2012) which examines both the positive and negative relationship between the two phenomena, which argues that income inequality refers to disparities in income distribution, ie to the difference between rich and poor. Moreover, (Barro, 2000) concludes that the effect of income inequality on economic growth is different depending on the state of economic development. Income inequality in poor countries delays economic growth, but income inequality in rich countries encourages economic growth. Romania is not among the rich and highly developed countries according to EUROSTAT statistics comparing the evolution of GDP in all member countries of the European Union (EU). Analyzing the two hypotheses, Romania would fall into the group of developed countries, which is debatable. This situation is also encountered in the analysis of the United States and France, cases of industrialized nations, according to reports in recent years the rate of economic growth of the United States is higher than that of France and yet the United States suffers a higher income inequality than France. According to case studies in the United States and France, we can assume that there is a positive relationship between income inequality and economic growth (Shin, 2012). This situation is also present in the case of Romania, being a developing country, income inequality encourages economic growth, proven by analyzing the relationship between the two factors, economic growth and income inequality, because the saving rate of rich people is higher than that of the poor. Redistributing income from rich to poor reduces the savings rate of the economy as a whole and could therefore lead to a decline in economic growth. Another reason is that the redistribution of income could reduce the incentive for the rich to work hard and this could also lead to a decline in economic growth. As a result, we can deduce that income equality makes economic growth lower and income inequality makes it higher. 


\section{Conclusions}

The present paper provides an overview of the negative relationship between economic growth and income inequality in Romania after 1990. There are several factors influencing economic growth phenomenon that contributed to the worsening of income distribution: transition to the market economy, employment, investment, governance and political factors, international crisis and influence of globalization There are also underestimated factors, with potential to contribute to a fair distribution of income. For instance, as Candidate State, Romania had the opportunity of pre-accession EU funds and now, as Member State, Romania has access to European funds, for extension of capital investments and human capital development, increase of national competitiveness, access to international markets through trade openness.

As future research directions, I intend to develop a deeper analysis regarding the factors influencing the relationship between economic growth and income inequality in Romania and European Union countries, such as: fiscal and economic policies and institutional factors.

\section{References:}

1. Aiyar, S., Ebeke, C. (2020) 'Inequality of opportunity, inequality of income and economic growth ', World Development, Vol. 136, pp 105115

2. Banerjee, A., Duflo, E. (2003) 'Inequality and growth: What can the data say?', Journal of Economic Growth - Springer, Vol. 8(3), pp 267-299.

3. Barro, R.J. (2000) 'Inequality and growth in a panel of countries', Journal of Economics. Vol. 5(1), pp.5-32.

4. Brueckner, M., et.al. (2015) 'National Income and its Distribution', Journal of Economic Growth - Springer, Vol. 20(2) (June), pp. 149 - 175.

5. Cingano, F. (2014) 'Trends in Income Inequality and its Impact on Economic Growth', OECD Social, Employment and Migration Working Paper, 163.

6. Ferge, Z. (1997) The Perils of the Welfare State's Withdrawal', Social Research, Vol.64, no.4, pp.1381-1402.

7. Forbes, K. (2000) 'A reassessment of the relationship between inequality and growth', American Economic Review, American Economic Association, Vol. 90(4), pp 869-887.

8. Galor, O., Zeira, J. (1993) 'Income distribution and macroeconomics', Review of Economic Studies, Vol. 60, pp 35-52.

9. Georgescu, G.(2013) Romania in post-crisis period: foreign direct investments and effects on external financial balance, MPRA Paper. no. 46531

10. Howarth, R.B., Kennedy, K, (2016) 'Economic growth, inequality, and wellbeing', Ecological Economics, Vol. 121, pp 231-236

11. Hsieh, C., et.al. (2013) 'The Allocation of Talent and U.S. Economic Growth', NBER Working Paper 18693 (Cambridge, Massachusetts: National Bureau of Economic Research).

12. Ionescu, C. (2005) 'Paradigmele dezvoltării', București: Editura Economică.

13. Kraay, A. (2015) ' Weak Instruments in Growth Regressions: Implications for Recent Cross-country Evidence on Inequality and Growth', Policy Research Working Paper Series 7494 (Washington: World Bank). 
14. Islam, M.R., McGillivray, M. (2020) ' Wealth inequality, governance and economic growth', Economic Modelling, Vol. 88 , pp 1-13

15. Kraay, A. (2015) 'Weak Instruments in Growth Regressions: Implications for Recent Cross-country Evidence on Inequality and Growth', Policy Research Working, Paper Series 7494 (Washington: World Bank).

16. Marrero, G., Rodríguez, J. (2013) 'Inequality of opportunity and growth', Journal of Development Economics, Vol. 104, pp 107-122.

17. Molnar, M. (2010) 'Inegalitatea veniturilor gospodăriilor în România',Revista $\begin{array}{llrrr}\text { Română de Statistică, } & \text { No.7, } & \text { pp. } & 18 .\end{array}$ (https://www.revistadestatistica.ro/Articole/2010/A3ro_7_2010.pdf) [9 November 2021]

18. Muinelo-Gallo, L., Roca-Sagalés, O. (2013) 'Joint determinants of fiscal policy, income inequality and economic growth', Economic Modelling 30, pp.814824.

19. Ostry, J., Berg, A. (2011) 'Inequality and Unsustainable Growth; Two Sides of the Same Coin?' IMF Staff Discussion Note No. 11/08 (Washington: International Monetary Fund).

20. Oustry, J.,et.al. (2014) 'Redistribution, Inequality, and Growth', IMF Staff Discussion Note No. 14/02 (Washington: International Monetary Fund).

21. Oxfam, (2016) ' An Economy for the 1\%', Oxfam GB for Oxfam International, Oxford.

22. Peterson, E.W.F. (2017) 'Is Economic Inequality Really a Problem? A Review of the Arguments', Social Sciences, MDPI, Vol. 6(4), pp. 1-25.

23. Shin, I. (2012) 'Income inequality and economic growth',Economic Modelling, Vol. 29. pp. 2049-2057.

24. Solt, F. (2020) 'Measuring Income Inequality Across Countries and Over Time: The Standardized World Income Inequality Database', Social Science Quarterly, vol.101, Issue 3, pp. 1183-1199. (https://onlinelibrary.wiley.com/doi/10.1111/ssqu.12795)

25. Stiglitz, J.E. (2013) 'The Price of Inequality', W. W. Norton, New York, NY.

26. The Standardized World Income Inequality Database, SWIID Version 9.1, May 2021

(https://dataverse.harvard.edu/dataset.xhtml?persistentld=doi:10.7910/DVN/L M4OWF) [8 November 2021]

27. Victor, P. (2008) 'Managing without growth', Edward Elgar, Cheltenham.

28. World Bank Data. World Development Indicators. GDP per capita, PPP (constant 2017 international USD)

(https://data.worldbank.org/indicator/NY.GDP.PCAP.PP.KD) [ 8 November 2021]

29. World Bank Data. World Development Indicators. GDP per capita growth (\%), (constant 2010 international USD)

(https://data.worldbank.org/indicator/NY.GDP.PCAP.KD.ZG) [ 28 November 2021] 